\title{
Communication \\ The Difference in Cytotoxic Activity between Two Optical Isomers of Gelsemine from Gelsemium elegans Benth. on PC12 Cells
}

\author{
Li Lin ${ }^{1}$, Yan-Chun Liu ${ }^{1,2}$ and Zhao-Ying Liu ${ }^{1,2, *(1)}$ \\ 1 College of Veterinary Medicine, Hunan Agricultural University, Changsha 410128, China; \\ linli.1110@foxmail.com (L.L.); lyc20180101@sina.com (Y.-C.L.) \\ 2 Hunan Engineering Technology Research Center of Veterinary Drugs, Hunan Agricultural University, \\ Changsha 410128, China \\ * Correspondence: liu_zhaoying@hunau.edu.cn; Tel.: +86-151-1117-9464
}

Academic Editors: Francesco Epifano and Serena Fiorito

Received: 2 May 2019; Accepted: 22 May 2019; Published: 25 May 2019

\begin{abstract}
Two optical isomers, +/- gelsemine (1,2), together with one known compound were isolated from the whole plant of G. elegans. The structures of the separated constituents were elucidated on 1D and 2D ( ${ }^{1} \mathrm{H}-{ }^{1} \mathrm{H}$ COSY, HMBC, HSQC) NMR spectroscopy and high-resolution mass spectrometry (HRMS). The isolated alkaloids were tested in vitro for cytotoxic potential against PC12 cells by the MTT assay. As a result, (+) gelsemine (compound 1) exhibited cytotoxic activity against PC12 cells with an $\mathrm{IC}_{50}$ value of $31.59 \mu \mathrm{M}$, while (-) gelsemine (compound 2) was not cytotoxic.
\end{abstract}

Keywords: Gelsemium elegans; gelsemine; koumine; PC12 cells

\section{Introduction}

Gelsemium elegans Benth. (G. elegans), referred to as "Gou-Wen" and "Duan-Chang-Cao" in China, belongs to Loganiaceae family and is a famous toxic plant that is widely distributed in Southeast Asia and southern China [1]. This plant has been used as a traditional medicine for the treatment of pain, spasticity, skin ulcers, migraines, neuralgia, sciatica, cancer, and various types of sores [2-8]. The Gelsemium genus includes three species, all of which have a large number of alkaloids, including indole, bisindole, and monoterpenoid alkaloids [7,9-11]. To date, more than 120 kinds of alkaloids, including some stereo-isomer compounds, have been isolated from G. elegans. Most of the alkaloids are classified into five types based on their chemical structure characteristics: gelsedine-, koumine-, humantenine-, sarpagine-, and gelsemine-type [5,12]. The Gelsemium alkaloids have potent cytotoxic, analgestic, anti-inflammatory, immunomodulating, and antiarrhythmic activities, which means they have potential as new drugs $[7,13]$. Their tremendous effects and the unusual and densely functionalized nature of the hexacyclic structure have been used in the development of synthetic approaches toward gelsemine, humantenine, and gelsedine-type alkaloids. The first total syntheses of $( \pm)$-gelsemine were disclosed in 1994 by the groups of Johnson. Gelsemine and koumine of G. elegans inhibited Tetrahymena thermophila cells' growth in a dose-dependent manner $[14,15]$. In the present study, two optical isomers, +/- gelsemine $(1,2)$, together with one known compound, koumine, were isolated from the whole plant of G. elegans (Figure 1). According to the structure of gelsemine, gelsemine has seven chiral carbon and two chiral nitrogen atoms. The structures of these compounds were elucidated mainly by NMR spectroscopic and high resolution mass spectroscopic methods. Furthermore, all compounds have been tested in vitro for cytotoxic potential against PC12 cells by MTT assay. 


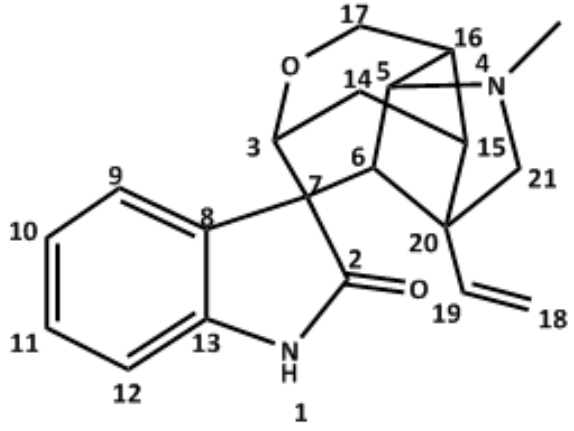

$1 / 2$

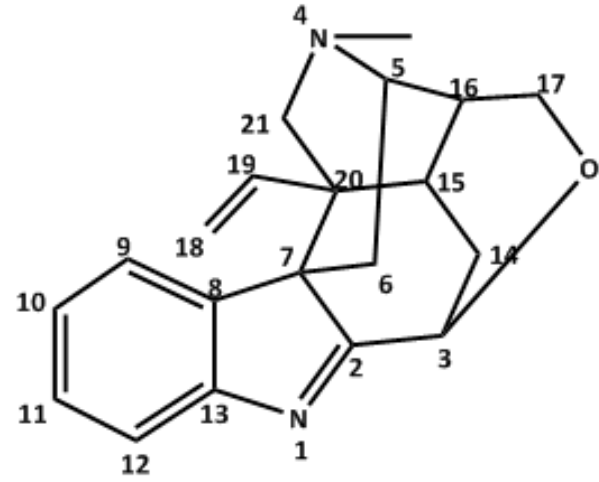

3

Figure 1. The structures of compound ( \pm )-gelsemine (1/2) and koumine (3).

\section{Results and Discussion}

Compound 1 was isolated as a white powder (for ${ }^{1} \mathrm{H}$ and ${ }^{13} \mathrm{C}-\mathrm{NMR}$, see Table 1 ). The molecular formula was determined as $\mathrm{C}_{20} \mathrm{H}_{23} \mathrm{~N}_{2} \mathrm{O}_{2}$ by HR-ESI-MS in positive mode $\left(\mathrm{m} / z 323.1758[\mathrm{M}+\mathrm{H}]^{+}\right.$, calcd for $[\mathrm{M}+\mathrm{H}]^{+} 323.1751$ ). The ${ }^{1} \mathrm{H}$ and ${ }^{13} \mathrm{C}-\mathrm{NMR}$ (See supplementary materials Figures S1-S6) profile of compound 1 matched with the reported data for gelsemine [16].

Compound $\mathbf{2}$ was isolated as a yellow powder and had similar NMR data to $\mathbf{1}$ (Table 1), but the purity of compound 2 was lower than 1 . The molecular formula was determined as $\mathrm{C}_{20} \mathrm{H}_{23} \mathrm{~N}_{2} \mathrm{O}_{2}$ by HR-ESI-MS in positive mode $\left(\mathrm{m} / z 323.1763[\mathrm{M}+\mathrm{H}]^{+}\right.$, calcd for $\left.[\mathrm{M}+\mathrm{H}]^{+} 323.1751\right)$. The retention time of compound 1 and 2 was $16.861 \mathrm{~min}$ and $16.619 \mathrm{~min}$, respectively. The MS ${ }^{2}$ spectra of compounds 1 and $\mathbf{2}$ are shown in Figure 2. The product ions of compounds $\mathbf{1}$ and $\mathbf{2}$ were quite similar. According to the data of ${ }^{1} \mathrm{H}$ and ${ }^{13} \mathrm{C}-\mathrm{NMR}$ (See supplementary materials Figures S7-S12), compound 2 was identified as gelsemine.

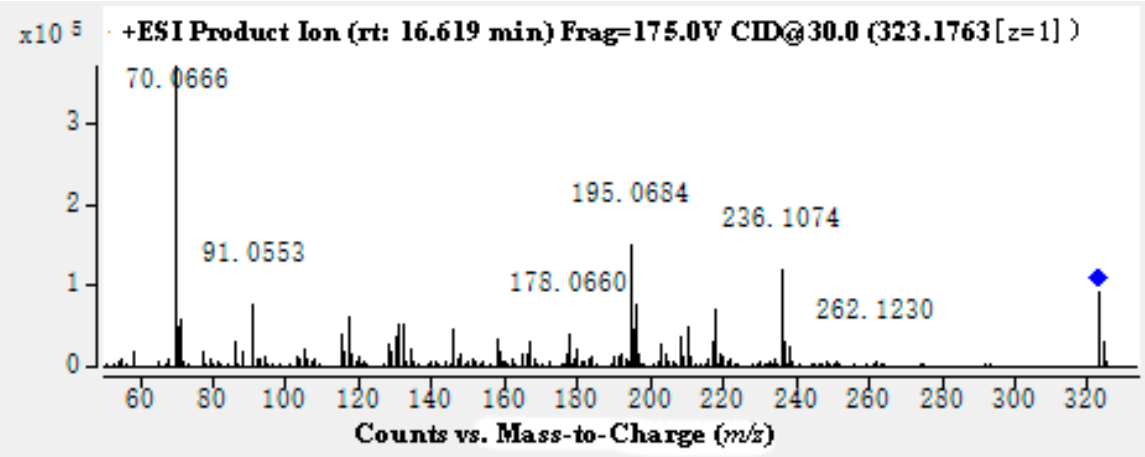

(a)

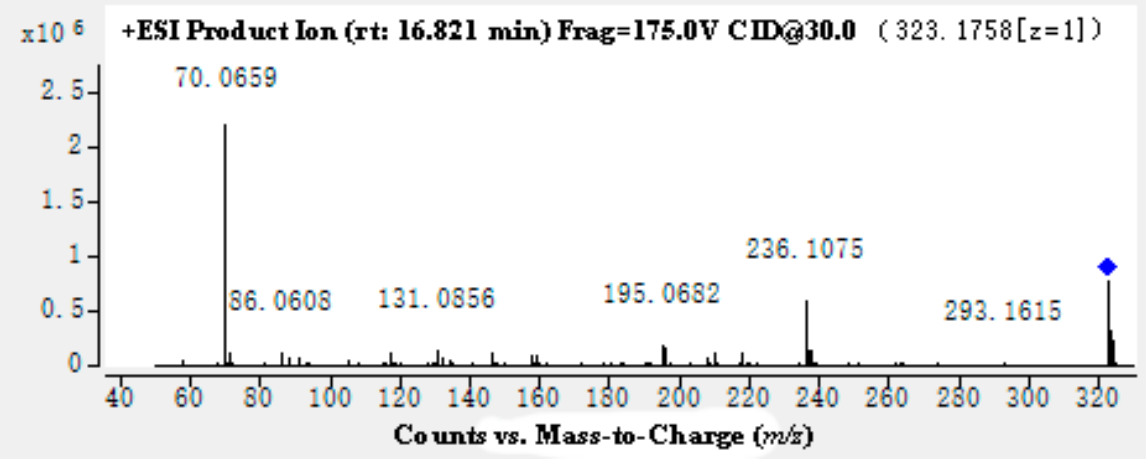

(b)

Figure 2. The MS/MS spectra of compound 1 (a) and 2 (b). 
Compound 3 was isolated as a yellow powder with the following properties: positive ESI-MS $m / z$ : 307.1812 [M + H] $]^{+},{ }^{13} \mathrm{C}-\mathrm{NMR}$ (See supplementary materials Figure S13) (101 MHz, MeOD) $\delta 187.85$ (2-C), 155.04 (13-C), 144.59 (8-C), 137.95 (19-C), 129.51 (11-C), 127.72 (10-C), 124.58 (9-C), 121.47 (12-C), 116.93 (18-C), 71.88 (3-C), 61.91 (17-C), 58.97 (7-C), 58.15 (21-C), 57.77 (5-C), 46.59 (20-C), 42.84 (N-Me), 38.52 (16-C), 33.97 (15-C), 30.46 (6-C), 25.93 (14-C). ${ }^{1} \mathrm{H}-\mathrm{NMR}$ (See supplementary materials Figure S14) (400 MHz, MeOD) $\delta 7.65(1 \mathrm{H}, \mathrm{d}, J=7.3 \mathrm{~Hz}, 12-\mathrm{H}), 7.55(1 \mathrm{H}, \mathrm{d}, \mathrm{J}=7.6 \mathrm{~Hz}, 9-\mathrm{H}), 7.40\left({ }^{1} \mathrm{H}, \mathrm{td}, J=7.6\right.$, $1.2 \mathrm{~Hz}, 11-\mathrm{H}), 7.33(1 \mathrm{H}, \mathrm{td}, J=7.5,1.0 \mathrm{~Hz}, 10-\mathrm{H}), 4.92(1 \mathrm{H}, \mathrm{dd}, \mathrm{J}=8.3,1.7 \mathrm{~Hz}, 18 \alpha-\mathrm{H}), 4.82(\mathrm{dd}, J=11.2$, $0.8 \mathrm{~Hz}, 1 \mathrm{H}, 18 \beta-\mathrm{H}), 4.69(1 \mathrm{H}, \mathrm{dd}, J=17.6,11.3 \mathrm{~Hz}, 19-\mathrm{H}), 4.32(1 \mathrm{H}, \mathrm{dd}, J=12.0,4.6 \mathrm{~Hz}, 17 \alpha-\mathrm{H}), 3.64$ $(1 \mathrm{H}, \mathrm{d}, \mathrm{J}=12.0 \mathrm{~Hz}, 17 \beta-\mathrm{H}), 3.29(1 \mathrm{H}, \mathrm{d}, J=11.9 \mathrm{~Hz}, 21 \alpha-\mathrm{H}), 3.03(1 \mathrm{H}, \mathrm{m}, 21 \beta-\mathrm{H}), 2.88(1 \mathrm{H}, \mathrm{m}, 5-\mathrm{H}), 2.67$ $(1 \mathrm{H}, \mathrm{s}, \mathrm{N}-\mathrm{Me}), 2.42(2 \mathrm{H}, \mathrm{m}, 6-\mathrm{H}), 1.87(\mathrm{dt}, J=14.8,2.0 \mathrm{~Hz}, 1 \mathrm{H}, 14 \beta-\mathrm{H})$. This profile was consistent with the reported NMR data for koumine [16].

Table 1. ${ }^{1} \mathrm{H}-\mathrm{NMR}(400 \mathrm{MHz})$ and ${ }^{13} \mathrm{C}-\mathrm{NMR}(100 \mathrm{MHz})$ data for Compound $\mathbf{1}$ and $\mathbf{2}$ in MeOD ( $\delta$ in ppm and $J$ in $\mathrm{Hz}$ ).

\begin{tabular}{|c|c|c|c|c|}
\hline \multirow{2}{*}{ Position } & \multicolumn{2}{|c|}{ Compound 1} & \multicolumn{2}{|c|}{ Compound 2} \\
\hline & $\delta_{C}$ & $\delta_{H}$ & $\delta_{C}$ & $\delta_{H}$ \\
\hline 2 & 179.26 & / & 180.56 & l \\
\hline 3 & 69.58 & $3.60(1 \mathrm{H}, \mathrm{s})$ & 70.97 & $3.64(1 \mathrm{H}, \mathrm{s})$ \\
\hline 5 & 71.81 & $4.12(1 \mathrm{H}, \mathrm{d}, 11.0)$ & 73.28 & $4.13(1 \mathrm{H}, \mathrm{d}, 11.0)$ \\
\hline 6 & 50.63 & $1.99(1 \mathrm{H}, \mathrm{s})$ & 51.93 & $2.01(1 \mathrm{H}, \mathrm{s})$ \\
\hline 7 & 54.19 & / & 55.55 & / \\
\hline 8 & 131.70 & / & 133.00 & / \\
\hline 9 & 127.99 & $7.46(1 \mathrm{H}, \mathrm{d}, 7.6)$ & 129.30 & $7.46(1 \mathrm{H}, \mathrm{d}, 7.6)$ \\
\hline 10 & 121.23 & $7.00(1 \mathrm{H}, \mathrm{t}, 7.6)$ & 122.65 & $7.00(1 \mathrm{H}, \mathrm{t}, 7.6)$ \\
\hline 11 & 128.10 & $7.22(1 \mathrm{H}, \mathrm{t}, 7.7)$ & 129.49 & $7.22(1 \mathrm{H}, \mathrm{t}, 7.7)$ \\
\hline 12 & 108.97 & $6.87(1 \mathrm{H}, \mathrm{d}, 7.7)$ & 110.40 & $6.87(1 \mathrm{H}, \mathrm{d}, 7.7)$ \\
\hline 13 & 141.20 & / & 142.60 & / \\
\hline 14 & 22.34 & $\begin{array}{c}2.04(1 \mathrm{H}, \mathrm{m}) \\
2.84(1 \mathrm{H}, \mathrm{dd}, 14.3,2.1)\end{array}$ & 23.70 & $\begin{array}{l}2.04(1 \mathrm{H}, \mathrm{m}) \\
2.84(1 \mathrm{H}, \mathrm{m})\end{array}$ \\
\hline 15 & 35.63 & $2.34(1 \mathrm{H}, \mathrm{t})$ & 36.98 & $2.38(1 \mathrm{H}, \mathrm{s})$ \\
\hline 16 & 37.50 & $2.49(1 \mathrm{H}, \mathrm{m})$ & 38.97 & $2.50(1 \mathrm{H}, \mathrm{m})$ \\
\hline 17 & 60.81 & $\begin{array}{l}3.97(1 \mathrm{H}, \mathrm{d}, 11.0) \\
\quad 3.72(1 \mathrm{H}, \mathrm{s})\end{array}$ & 62.14 & $\begin{array}{c}3.97(1 \mathrm{H}, \mathrm{m}) \\
3.72(1 \mathrm{H}, \mathrm{s})\end{array}$ \\
\hline 18 & 111.59 & $\begin{array}{l}4.98(1 \mathrm{H}, \mathrm{d}, 17.8) \\
5.05(1 \mathrm{H}, \mathrm{d}, 11.0)\end{array}$ & 113.16 & $\begin{array}{l}4.98(1 \mathrm{H}, \mathrm{d}, 17.8) \\
5.06(1 \mathrm{H}, \mathrm{d}, 11.0)\end{array}$ \\
\hline 19 & 138.31 & $6.26(1 \mathrm{H}, \mathrm{dd}, 17.8,11.0)$ & 139.48 & $\begin{array}{c}6.25(1 \mathrm{H}, \mathrm{dd}, 17.8, \\
11.0)\end{array}$ \\
\hline 20 & 53.68 & / & 55.02 & l \\
\hline 21 & 65.17 & $\begin{array}{l}2.78(1 \mathrm{H}, \mathrm{d}, 10.8) \\
3.33(1 \mathrm{H}, \mathrm{d}, 1.3)\end{array}$ & 66.45 & $2.80(1 \mathrm{H}, \mathrm{d}, 10.7)$ \\
\hline N-CH3 & 39.03 & $2.28(3 \mathrm{H}, \mathrm{s})$ & 40.43 & $2.31(3 \mathrm{H}, \mathrm{s})$ \\
\hline
\end{tabular}

The effects of the three compounds on the activity of poorly differentiated PC-12 cells and highly differentiated PC-12 cells (Figure 3) were investigated, and it was found that only compound 1 inhibited viability in highly differentiated PC-12 cells, while the other compounds were not toxic to either type of PC-12 cells. As shown in Table 2, compound 1 on poorly differentiated PC-12 cells showed no toxicity $\left(\mathrm{IC}_{50}>100 \mu \mathrm{M}\right)$, and did not affect its activity. However, compound 1 showed toxicity to highly differentiated PC-12 cells and decreased cell activity, and its $\mathrm{IC}_{50}$ was $31.59 \mu \mathrm{M}$. The results indicated that compound 1 exhibited some cytotoxic activity against PC12 cells, while compound 2 did not. 2D ( ${ }^{1} \mathrm{H}-{ }^{1} \mathrm{H}$ COSY, HMBC, HSQC) NMR spectroscopy (Figures S1-S12) showed that compounds $\mathbf{1}$ and $\mathbf{2}$ are quite similar. However, the optical rotation results showed that compound $\mathbf{1}$ and $\mathbf{2}$ are two optical isomers of gelsemine $\left(\mathbf{1}:{ }_{[\alpha}\right] 25 \mathrm{D}=793.79(\mathrm{c}=0.047, \mathrm{MeOH}),{ }_{2}:[\alpha] 25 \mathrm{D}=-909.09(\mathrm{c}=0.025$, $\mathrm{MeOH})$ ) which explained why they differ in cytotoxic activity on PC12 cells. 

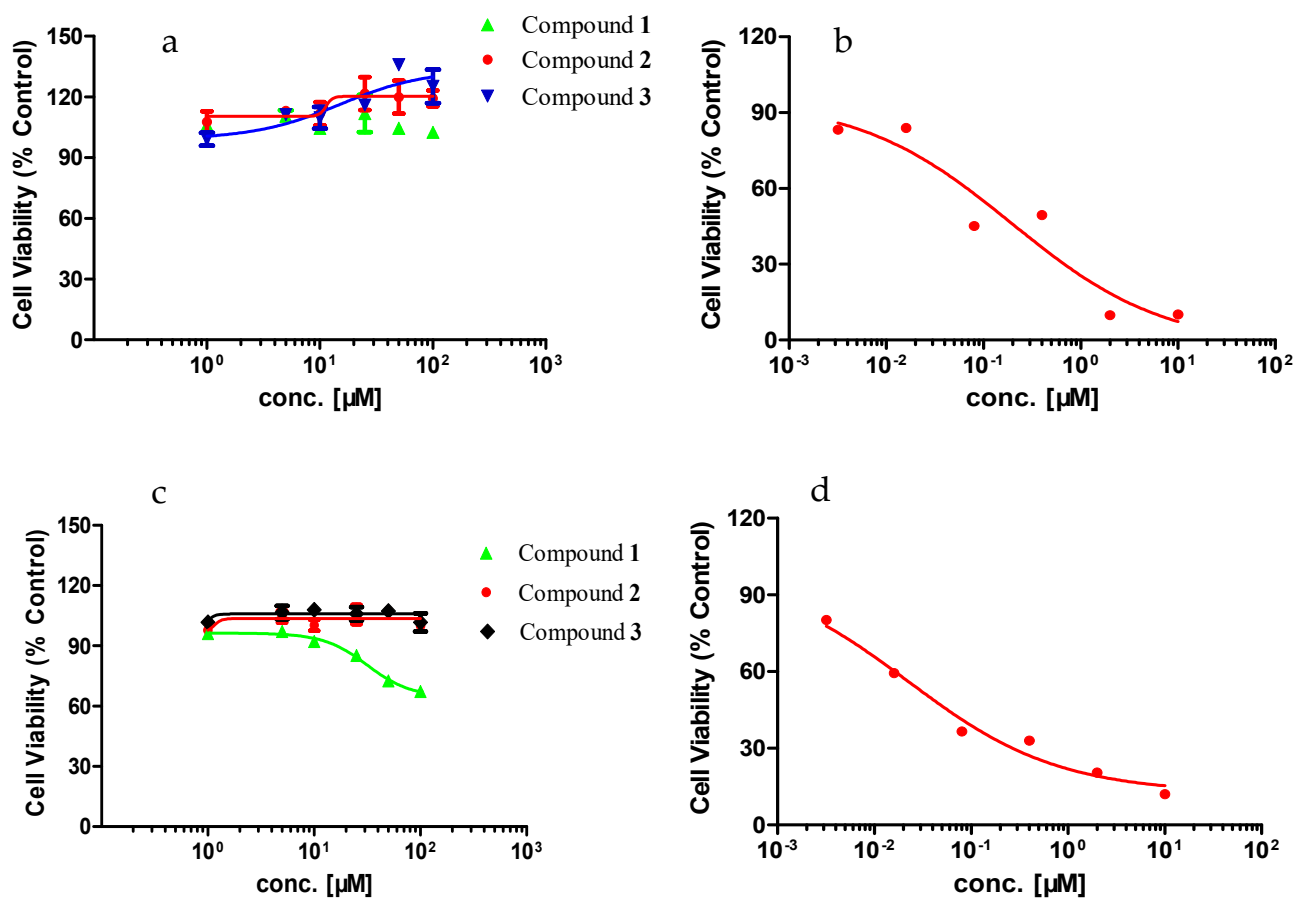

Figure 3. The cell viability of the three compounds in a series of concentrations $(5,10,25,50,100 \mu \mathrm{M})$ and positive drug staurosporine (STSP) on two types of PC-12 cells after exposure for $48 \mathrm{~h}$. (a) the three compounds' concentration responses of poorly differentiated PC-12 cells; (b) STSP concentration response in poorly differentiated PC-12 cells; (c) the three compounds' concentration responses in highly differentiated PC-12 cells; (d) STSP concentration response in highly differentiated PC-12 cells.

Table 2. Cytotoxicity of compounds $1-3$ against PC12 cell lines $\left(\mathrm{IC}_{50}, \mu \mathrm{M}\right)$

\begin{tabular}{ccc}
\hline Compound & PC12 Highly Differentiated Cells & PC12 Poorly Differentiated Cells \\
\hline $\mathbf{1}$ & $>100$ & 31.59 \\
$\mathbf{2}$ & $>100$ & $>100$ \\
$\mathbf{3}$ & $>100$ & $>100$ \\
STSP & 0.1944 & 0.022 \\
\hline
\end{tabular}

\section{Materials and Methods}

\subsection{General Experimental Procedures}

NMR spectra were acquired using a Bruker ACF-400 spectrometer (the ${ }^{1} \mathrm{H}-\mathrm{NMR}$ spectra at $400 \mathrm{MHz}$ and ${ }^{13} \mathrm{C}-\mathrm{NMR}$ spectra at $100 \mathrm{MHz}$, (Bruker, Rheinstetten, Germany). The mass spectra were determined by an Agilent 1290 HPLC system (Agilent Technologies, California, CA, USA) coupled with a 6530 Q-TOF/MS accurate-mass spectrometry. Silica gel (100-200, 200-300, 300-400 mesh) was used for column chromatography (CC) and silica GF254 for TLC was supplied by Qingdao Haiyang Chemical Factory, Qingdao, RP China. All solvents used were of analytical grade and obtained from Shanghai Chemical Reagents Company, Shanghai, RP China. Acetonitrile and methanol used for chromatographic grade were purchased from Merck, German. PC12 cells were purchased from Cell bank of Chinese academy of sciences. Staurosporine (STSP) was obtained from MedChem Express, Shanghai, China.

\subsection{Plant Material}

The whole plant of G. elegans was collected from Longyan city, Fujian province (24.699739 N, 116.98967 E). The samples were authenticated by Dr Qi Tang at Hunan Agricultural University. 


\subsection{Extraction and Isolation}

The air-dried whole plant of G. elegans $(100 \mathrm{~kg})$ was powdered and extracted two times $(2 \times 24 \mathrm{~h})$ with $0.5 \%$ sulfuric acid solution $(100 \mathrm{~L})$ at room temperature. The extracted solution was filtered through a 200-mesh filter and combined, then was basified with $\mathrm{NaOH}(8 \mathrm{~mol} / \mathrm{L})$ to $\mathrm{pH} 7.0$, and dried under reduced pressure. Then, the fraction $(1 \mathrm{~kg})$ was extracted by reflux in $1.5 \mathrm{~L}$ of $95 \%$ ethanol for twice times (each for $2 \mathrm{~h}$ ). After filtration, the extract was combined and concentrated under reduced pressure. The ethanol fraction (138 g) was further fractionated through a silica gel column chromatography (CC), eluting with $\mathrm{CH}_{2} \mathrm{Cl}_{2}-\mathrm{MeOH}$ (from 100:0 to 0:100, v/v) to obtain 14 fractions according to TLC analysis (Frs. 1-14). Fraction 7 (2.85 g) was subjected to silica gel CC $\left(\mathrm{CH}_{2} \mathrm{Cl}_{2}-\mathrm{MeOH}\right.$ -ammonia, 95:5:0.05, v/v/v) to afford compound 1 (78 mg). Fraction 3 (5.00 g) was subjected to silica gel CC $\left(\mathrm{CH}_{2} \mathrm{Cl}_{2}-\mathrm{MeOH}\right.$-ammonia, 95:5:0.05-90:10:0.05, v/v/v) to afford three subfractions (Fr. 3-1 and Fr. 3-3). Fr. 3-1 (0.50 g) was subjected to silica gel CC $\left(\mathrm{CH}_{2} \mathrm{Cl}_{2}-\mathrm{MeOH}\right.$-ammonia, 20:0.8:0.05, v/v/v) to obtain compound 2 (71 $\mathrm{mg}$ ) and compound 3 (99 $\mathrm{mg})$.

\subsection{Cell Line and Culture}

Poorly differentiated PC-12 cells: PC12 cells (Cell bank of Chinese academy of sciences) were grown in $100 \mathrm{~cm}^{2}$ culture flasks $\left(1 \times 10^{6}\right.$ cells per flask) at $37^{\circ} \mathrm{C}$ in serum-containing medium, $85 \%$ RPMI 1640, 10\% heat-inactivated horse serum (Gibco, Grand Island, NY, USA ), 5\% fetal calf serum (Biowest, Nuaillé, France ), penicillin \& streptomycin (1× P/S, Procell, Tongxiang, China, Lot: 16050130) and no NGF. Culture medium was exchanged three times weekly. Highly differentiated PC-12 cells: PC-12 cells were grown in serum-containing medium (90\% RPMI 1640,10\% fetal calf serum, $1 \times \mathrm{P} / \mathrm{S}$ ), treated with $20 \mathrm{ng} / \mathrm{mL}$ of NGF (Sigma, San Francisco, CA, USA, Lot: SRP3018). The medium was changed every 2-3 days and NGF was added if required.

Supplementary Materials: The following are available online, Figure S1: The ${ }^{13} \mathrm{C}-\mathrm{NMR}$ spectrum of compound 1, Figure S2. The ${ }^{1} \mathrm{H}-\mathrm{NMR}$ spectrum of compound 1, Figure S3: The ${ }^{1} \mathrm{H}_{-}{ }^{1} \mathrm{H}$ COSY spectrum of compound 1, Figure S4: The HMBC spectrum of compound 1, Figure S5: The HSQC spectrum of compound 1, Figure S6: The DEPT135 spectrum of compound 1, Figure S7: The ${ }^{13} \mathrm{C}-\mathrm{NMR}$ spectrum of compound 2, Figure S8: The ${ }^{1} \mathrm{H}-\mathrm{NMR}$ spectrum of compound 2, Figure S9: The 1H-1H COSY spectrum of compound 2, Figure S10: The HMBC spectrum of compound 2, Figure S11: The HSQC spectrum of compound 2, Figure S12: The DEPT135 spectrum of compound 2, Figure S13: The ${ }^{13} \mathrm{C}-\mathrm{NMR}$ spectrum of compound 3, Figure S14: The ${ }^{1} \mathrm{H}-\mathrm{NMR}$ spectrum of compound 3.

Author Contributions: Z.-Y.L. conceived and designed the experiments; Y.-C.L. performed extraction, isolation, MS experiment; L.L. performed NMR experiments and contributed to the preparation of the manuscript; Z.-Y.L. revised the manuscript.

Funding: Support was received from the Hunan Provincial Natural Science Foundation of China (Grant No. 2017JJ1017)

Conflicts of Interest: The authors declare no conflict of interest.

\section{References}

1. Zhang, W.; Xu, W.; Wang, G.Y.; Gong, X.Y.; Li, N.P.; Wang, L.; Ye, W.C. Gelsekoumidines A and B: Two Pairs of Atropisomeric Bisindole Alkaloids from the Roots of Gelsemium elegans. Org. Lett. 2017, 19, 5194. [CrossRef]

2. Sun, M.X.; Gao, H.H.; Zhao, J.; Zhang, L.; Xiao, K. New oxindole alkaloids from Gelsemium elegans. Tetrahedron Lett. 2015, 56, 6194-6197. [CrossRef]

3. Noriyuki, K.; Naoko, I.; Mariko, K.; Sumphan, W.; Hiromitsu, T. Four novel gelsenicine-related oxindole alkaloids from the leaves of Gelsemium elegans benth. Org. Lett. 2006, 8, 3085-3088.

4. Jin, G.L.; Su, Y.P.; Liu, M.; Xu, Y.; Yang, J.; Liao, K.J.; Yu, C.X. Medicinal plants of the genus Gelsemium (Gelsemiaceae, Gentianales) - A review of their phytochemistry, pharmacology, toxicology and traditional use. J. Ethnopharmacol. 2014, 152, 33-52. [CrossRef] [PubMed]

5. Kitajima, M. Chemical studies on monoterpenoid indole alkaloids from medicinal plant resources Gelsemium and Ophiorrhiza. J. Nat. Med. 2007, 61, 14-23. [CrossRef] 
6. Xu, Y.K.; Yang, L.; Liao, S.G.; Cao, P.; Wu, B.; Hu, H.B.; Guo, J.; Zhang, P. Koumine, Humantenine, and Yohimbane Alkaloids from Gelsemium elegans. J. Nat. Prod. 2015, 78, 1511-1517. [CrossRef] [PubMed]

7. Lei, W.; Wang, J.F.; Xia, M.; Li, J.; Wang, X.J. Gelsedine-type oxindole alkaloids from Gelsemium elegans and the evaluation of their cytotoxic activity. Fitoterapia 2017, 120, 131.

8. Liu, Y.C.; Lin, L.; Cheng, P.; Sun, Z.L.; Wu, Y.; Liu, Z.Y. Fingerprint analysis of Gelsemium elegans by HPLC followed by the targeted identification of chemical constituents using HPLC coupled with quadrupole-time-of-flight mass spectrometry. Fitoterapia 2017, 121, 94-105. [CrossRef] [PubMed]

9. Zhang, Z.; Zhang, Y.; Wang, Y.H.; Zhang, Q.; Yan, X.H.; Di, Y.T.; He, H.P.; Hao, X.J. Three novel beta-carboline alkaloids from Gelsemium elegans. Fitoterapia 2012, 83, 704-708. [CrossRef] [PubMed]

10. Liang, S.; He, C.Y.; Szabo, L.F.; Feng, Y.; Lin, X.; Wang, Y. Gelsochalotine, a novel indole ring-degraded monoterpenoid indole alkaloid from Gelsemium elegans. Tetrahedron Lett. 2013, 54, 887-890. [CrossRef]

11. Qu, J.; Fang, L.; Ren, X.D.; Liu, Y.B.; Yu, S.S.; Li, L.; Bao, X.Q.; Zhang, D.; Li, Y.; Ma, S.G. Bisindole Alkaloids with Neural Anti-inflammatory Activity from Gelsemium elegans. J. Nat. Prod. 2013, 76, 2203-2209. [CrossRef] [PubMed]

12. Kitajima, M.; Kogure, N.; Yamaguchi, K.; Takayama, H.; Aimi, N. Structure reinvestigation of gelsemoxonine, a constituent of Gelsemium elegans, reveals a novel, azetidine-containing indole alkaloid. Org. Lett. 2003, 5, 2075. [CrossRef] [PubMed]

13. Fang, L.; Zhou, J.; Lin, Y.L.; Wang, X.; Sun, Q.; Li, J.L.; Huang, L. Large-scale separation of alkaloids from Gelsemium elegans by $\mathrm{pH}$-zone-refining counter-current chromatography with a new solvent system screening method. J. Chromatogr. A 2013, 1307, 80-85. [CrossRef] [PubMed]

14. Ye, Q.; Zhang, C.; Wang, Z.; Feng, Y.; Zhou, A.; Xie, S.; Xiang, Q.; Song, E.; Zou, J. Induction of oxidative stress, apoptosis and DNA damage by koumine in Tetrahymena thermophila. PLoS ONE 2019, 14, e0212231. [CrossRef] [PubMed]

15. Ye, Q.; Feng, Y.Y.; Wang, Z.L.; Jiang, W.Z.; Qu, Y.X.; Zhang, C.N.; Zhou, A.G.; Xie, S.L.; Zou, J.X. Effects of gelsemine on oxidative stress and DNA damage responses of Tetrahymena thermophila. Peer J 2018, 6, e6093. [CrossRef] [PubMed]

16. Su, Y.P.; Shen, J.; Xu, Y.; Zheng, M.; Yu, C.X. Preparative separation of alkaloids from Gelsemium elegans Benth. using $\mathrm{pH}$-zone-refining counter-current chromatography. J. Chromatogr. A 2011, 1218, 3695-3698. [CrossRef] [PubMed]

Sample Availability: Samples of the compounds are not available from the authors.

(C) 2019 by the authors. Licensee MDPI, Basel, Switzerland. This article is an open access article distributed under the terms and conditions of the Creative Commons Attribution (CC BY) license (http://creativecommons.org/licenses/by/4.0/). 